\title{
PRODUKSI IKAN LELE CEPAT TUMBUH GENERASI F-0 MENGGUNAKAN METODE TRANSGENESIS
}

\author{
Raden Roro Sri Pudji Sinarni Dewi, Huria Marnis, Rommy Suprapto, \\ dan Narita Syawalia \\ Balai Penelitian Pemuliaan Ikan \\ Jl. Raya 2 Sukamandi, Subang, Jawa Barat \\ E-mail: wiewie_thea@yahoo.com
}

(Naskah diterima: 26 November 2012; Disetujui publikasi: 12 Februari 2013)

\begin{abstract}
ABSTRAK
Penggunaan teknologi transgenesis untuk memproduksi ikan cepat tumbuh telah berhasil dilakukan pada beberapa spesies ikan budidaya. Pada penelitian ini dilakukan introduksi gen hormon pertumbuhan ikan patin siam (Pangasianodon hypophthalmus growth hormone, PhGH) menggunakan teknik elektroforasi pada sperma ikan lele (Clarias gariepinus) untuk memproduksi ikan lele cepat tumbuh generasi F-0. Hasil penelitian menunjukkan gen PhGH mampu terinsersi dan terekspresi secara genotip dan fenotip pada ikan lele. Transfer gen PhGH pada konsentrasi $100 \mu \mathrm{g} / \mathrm{mL}$ memiliki tingkat keberhasilan insersi gen terbaik yaitu sebesar $56 \%$. Berdasarkan pemeriksaan ekspresi mRNA gen PhGH menunjukkan bahwa terjadi over-ekspresi gen PhGH pada sirip individu yang positif membawa transgen. Individu ikan lele dalam populasi yang diintroduksi gen $\mathrm{PhGH}$ memiliki bobot badan yang lebih bervariasi dibandingkan kontrol. Berdasarkan distribusi bobot ikan lele, terdapat dua individu pada populasi hasil introduksi gen $\mathrm{PhGH}$ yang memiliki bobot hampir dua kali lipat dibandingkan bobot rata-rata populasi kontrol. Berdasarkan hasil penelitian ini maka telah terjadi over-ekspresi secara genotip dan fenotip pada generasi F-0 ikan lele cepat tumbuh.
\end{abstract}

KATA KUNCI: ikan lele, transgenesis, cepat tumbuh, gen PhGH

ABSTRACT: Production of F-O generation of fast-growing African catfish by transgenesis. By: Raden Roro Sri Pudji Sinarni Dewi, Huria Marnis, Rommy Suprapto, and Narita Syawalia

The use of transgenesis technology to generate fast-growing fish generation has been successfully performed on several species of fish. In the present study, growth hormone gene of stripped catfish (PhGH) was introduced to African catfish sperm to produce F-O generation of fast-growing African catfish. The results showed that PhGH gene was inserted and expressed in African catfish. Gene transfer at a concentration of $100 \mathrm{\mu g} \mathrm{PhGH} / \mathrm{mL}$ showed the best insertion rate that was equal to $56 \%$. Based on mRNA expression of PhGH gene, examination showed that there was over-expression in individual positively carrying transgene. Individual catfish in the population of the introduced gene PhGH had a more varied body weight than controls. However, based on the weight distribution of catfish, there were two individuals in the population of the introduced gene PhGH which weighed nearly twice the average weight of the control population. Based on the results, there have been over-expression in genotype and phenotype in the F-O generation of fast-growing catfish.

KEYWORDS: African catfish, transgenesis, fast-growing, PhGH gene 


\section{PENDAHULUAN}

Peningkatan populasi manusia di dunia secara signifikan menuntut adanya peningkatan ketersediaan pangan secara signifikan pula. Perikanan sebagai bidang yang turut menyumbang protein hewani dituntut pula untuk meningkatkan produksinya. Produksi budidaya dapat ditingkatkan melalui ketersediaan induk dan benih unggul. Secara genetika, induk/benih unggul dapat diperoleh antara lain dengan menggunakan metode seleksi, hibridisasi, poliploidisasi, transgenesis, dan sebagainya.

Perkembangan teknologi rekayasa genetika pada saat ini memungkinkan untuk memproduksi induk dengan karakteristik tertentu seperti pertumbuhan yang cepat, resisten terhadap penyakit, memiliki toleransi terhadap kondisi lingkungan yang ekstrim dan sebagainya. Teknologi yang digunakan untuk memproduksi induk ini adalah teknologi transgenesis. Penggunaan teknologi transgenesis memungkinkan untuk mendapatkan induk unggul dalam waktu yang relatif lebih singkat dibandingkan teknik seleksi konvensional dengan peningkatan perbaikan karakter yang lebih signifikan.

Secara umum, proses produksi hewan transgenik terdiri atas beberapa tahapan yang dapat diringkas seperti berikut: (1) identifikasi gen yang diinginkan (gen target), (2) isolasi gen target, (3) amplifikasi gen target untuk memproduksi beberapa kopi, (4) penggabungan gen target dengan promoter yang tepat dan sekuens poly A serta insersi ke dalam plasmid, (5) multiplikasi plasmid dalam bakteri dan recovery konstruksi kloning untuk injeksi, (6) transfer konstruksi ke dalam jaringan resipien, (7) integrasi gen ke dalam genom resipien, (8) ekspresi gen pada genom resipien, dan (9) pewarisan gen pada generasi selanjutnya (Beardmore \& Porter, 2003).

Devlin et al. (1994) melaporkan bahwa pertumbuhan dapat dipercepat dengan mengintroduksi gen yang mengkodekan hormon pertumbuhan $(\mathrm{GH}$, growth hormone) yang mensintesa peptida $\mathrm{GH}$ dalam jumlah yang besar (over-ekspresi). Transfer gen $\mathrm{GH}$ telah diaplikasikan pada beberapa spesies ikan budidaya dan terbukti mampu meningkatkan pertumbuhannya. Over-ekspresi gen GH pada ikan mud loach mampu meningkatkan pertumbuhan lebih dari 32 kali (Nam et al., 2001), pada ikan nila 2-7 kali (Kobayashi et al., 2007), salmon Coho sepuluh kali (Devlin et al., 1995), ikan mas tiga kali (Hinits \& Moav, 1999) dan salmon Atlantik 2-6 kali (Du et al., 1992) pada generasi kedua.

Penggunaan teknologi transgenesis di Indonesia untuk memproduksi ikan lele cepat tumbuh dimulai sejak tahun 2008. Penelitian Gusrina et al. (2009) menunjukkan bahwa mikroinjeksi gen mBP-tiGH pada embrio ikan lele dengan dosis $50 \mu \mathrm{g} / \mathrm{mL}$ menghasilkan $42,86 \%$ individu yang positif membawa transgen pada sirip ekornya. Namun demikian penggunaan metode mikroinjeksi pada embrio ikan lele memiliki kelemahan antara lain yaitu memerlukan tingkat keterampilan yang tinggi dalam aplikasinya, telur yang diinjeksi seringkali pecah dan menempel pada jarum mikroinjeksi, dan jumlah embrio yang berhasil menetas dan hidup sampai menjadi dewasa sangat rendah dibandingkan dengan jumlah telur yang dihasilkan ikan lele sehingga peluang mendapatkan induk ikan lele yang mampu mentransmisikan transgen pada anakannya sangat rendah.

Untuk mengatasi hal ini, maka Balai Penelitian Pemuliaan Ikan mencoba menggunakan metode lain untuk memproduksi ikan lele cepat tumbuh. Metode yang digunakan untuk mentransfer gen $\mathrm{GH}$ pada ikan lele adalah elektroforasi melalui perantaraan sperma. Keberhasilan transfer gen pada hewan akuatik dengan menggunakan teknik elektroforasi pada sperma sebelum fertilitasi terbukti pada ikan zebra (Powers et al., 1992), ikan ayu (Cheng et al., 2002), ikan loach (Tsai et al., 1995), dan ikan patin siam (Dewi, 2010). Efisiensi transfer gen ke dalam telur ikan ayu melalui elektroforasi pada sperma sebesar $55 \%$ (Cheng et al., 2002), lebih baik dibandingkan dengan ikan loach sebesar 50\% (Tsai et al., 1995), tetapi lebih rendah bila dibandingkan pada ikan zebra yaitu sebesar $80 \%$ (Powers et al., 1992) dan ikan patin siam yaitu sebesar 85\% (Dewi, 2010). Dibandingkan dengan teknik mikroinjeksi dan elektroforasi konvensional, teknik transfer gen melalui elektroforasi pada sperma relatif mudah dan efisien, karena ribuan telur dapat diproses dalam waktu yang bersamaan dengan menggunakan teknik fertilisasi buatan (Cheng et al., 2002).

Pada penelitian ini, konstruksi gen yang digunakan adalah all fish yang tersusun dari gen $\mathrm{GH}$ yang berasal dari patin siam $(\mathrm{PhGH})$ dan promoter $\beta$-aktin dari ikan mas ( $\mathrm{pCcBA}$ ). Transfer gen $\mathrm{PhGH}$ dilakukan dengan meng- 
gunakan metode elektroforasi pada sperma ikan lele yang berperan sebagai media pembawa transgen. Diharapkan transfer gen $\mathrm{PhCH}$ ini mampu menghasilkan generasi F-0 ikan lele yang mempunyai karakter cepat tumbuh.

\section{BAHAN DAN METODE}

\section{Preparasi Konstruksi Plasmid}

Konstruksi gen yang digunakan dalam penelitian ini tersusun dari promoter $\beta$-aktin ikan mas dan gen hormon pertumbuhan ikan patin siam (pCcBA-PhGH). Plasmid yang mengandung konstruksi gen pCcBA-PhGH diisolasi dari bakteri Eschericia coli. Satu koloni bakteri yang mengandung plasmid rekombinan ditumbuhkan di dalam $2 \mathrm{~mL}$ media Luria Bertani (LB) $(10 \mathrm{~g} / \mathrm{L}$ polypeptone; $5 \mathrm{~g} / \mathrm{L}$ yeast extract; $10 \mathrm{~g} / \mathrm{L} \mathrm{NaCl} ; \mathrm{pH} 7,5)$ yang mengandung kanamycin $100 \mathrm{mg} / \mathrm{L}$ pada shaker dengan kecepatan $250 \mathrm{rpm}$, suhu $37^{\circ} \mathrm{C}$ selama semalam. Bakteri diendapkan dengan sentrifugasi pada kecepatan $10.000 \mathrm{rpm}$, suhu $4^{\circ} \mathrm{C}$, selama sepuluh menit. Pelet yang terbentuk digunakan sebagai sampel untuk isolasi plasmid dengan menggunakan kit GF-1 Plasmid DNA Extraction (Vivantis) sesuai dengan prosedur pada manualnya.

\section{Koleksi Gamet}

Induk jantan dan betina yang digunakan adalah induk ikan lele berukuran sekitar $1 \mathrm{~kg}$ yang diperoleh dari Balai Penelitian Pemuliaan Ikan Sukamandi, Jawa Barat. Induk diseleksi berdasarkan tingkat kematangan gonadnya. Induk betina yang telah mencapai TKG III dipilih untuk dipijahkan. Induk hasil seleksi dari kolam induk dipindahkan ke dalam bak pemijahan.

Keseragaman kematangan telur dan ovulasi diinduksi melalui penyuntikan hormon. Induk betina disuntik ovaprim dengan dosis $0,2 \mathrm{~mL} / \mathrm{kg}$ bobot. Stripping untuk mendapatkan sel telur dilakukan 6-8 jam dari penyuntikan. Untuk mendapatkan sperma, induk jantan diinduksi melalui penyuntikan hormon ovaprim dengan dosis $0,1 \mathrm{~mL} / \mathrm{kg}$ bobot. Sperma diperoleh melalui pembedahan jaringan testes yang dilakukan 6-8 jam setelah penyuntikan.

\section{Pengujian Konsentrasi DNA terhadap Keberhasilan Transfer Gen}

Pengujian beberapa level konsentrasi pCCBA-PhGH dilakukan untuk mendapatkan konsentrasi terbaik menghasilkan ikan transgenik. Konsentrasi DNA plasmid yang diujikan adalah 50 dan $100 \mu \mathrm{g} / \mathrm{mL}$. Transfer gen dilakukan dengan menggunakan metode elektroforasi dengan perantara sperma. Elektroforasi sperma dilakukan dengan menggunakan mesin Gene Pulser II (Biorad, USA). Sperma diencerkan dengan menggunakan larutan fisiologis $(1: 1)$ sebelum dicampur dengan plasmid. Elektroforasi dilakukan dengan tipe kejutan square wave dengan panjang kejutan (pulse length) 30 milidetik dan interval kejutan (pulse interval) 0,1 detik, kuat medan listrik (electric field strength) $125 \mathrm{~V} / \mathrm{cm}$, dan jumlah kejutan (pulse number) lima kali.

\section{Efektivitas Transfer Gen PhGH}

Keberhasilan transfer gen pCcBA-PhGH diidentifikasi pada yuwana ikan lele berumur dua bulan. Ikan lele dipotong sebagian sirip ekornya untuk kemudian dilakukan ekstraksi DNA genom. Selanjutnya dilakukan proses PCR untuk mendeteksi keberadaan gen PhGH. Primer yang digunakan adalah FphGH1 (5'- TAG AGT GTT GGT GGT GCT CTC TGT -3') dan RphGH2 (5'- CGA TAA GCA CGC CGA TGC CCA TTT-3'). Ukuran fragmen gen GH eksogen adalah 392 bp. Proses PCR dilakukan pada kondisi: denaturasi $\left(94^{\circ} \mathrm{C}, 30\right.$ detik), annealing $\left(53^{\circ} \mathrm{C}\right.$, 30 detik), dan ekstensi $\left(72^{\circ} \mathrm{C}\right.$, satu menit) sebanyak 35 siklus. Pengecekan hasil amplifikasi PCR dilakukan dengan elektroforesis menggunakan gel agarose 1,5\%.

\section{Ekspresi Genotip dan Fenotip Gen PhGH}

Ekspresi gen $\mathrm{PhGH}$ diamati dari 12 ekor ikan lele yang positif membawa gen $\mathrm{PhGH}$ pada sirip ekornya. Sebagian sirip ekor ikan patin siam yang positif membawa gen $\mathrm{PhGH}$ dipotong untuk selanjutnya dilakukan ekstraksi RNA total. Sintesis cDNA dilakukan dengan menggunakan kit Ready-To-Go YouPrime First Strand Beads (GE Healthcare). Ekspresi gen PhGH eksogen dideteksi dengan menggunakan teknik RT-PCR menggunakan primer FphGH1 dan RphGH2. Sebagai kontrol internal digunakan gen $\beta$-aktin. Deteksi gen $\beta$ aktin dilakukan dengan menggunakan metode RT-PCR dengan primer bact-F (5'-TAT GAA GGT TAT GCT CTC CCC-3') dan bact-R (5'- CAT ACC CAG GAA AGA TGG CTG-3'). Panjang fragmen $\beta$-aktin ikan patin siam yang diapit oleh kedua primer tersebut sekitar 300 bp. PCR dilakukan dengan program: $94^{\circ} \mathrm{C}$ selama tiga menit; $\left(94^{\circ} \mathrm{C}\right.$ 
selama 30 detik; $58^{\circ} \mathrm{C}$ selama 30 detik; $72^{\circ} \mathrm{C}$ selama 30 detik) sebanyak 30 siklus; $72^{\circ} \mathrm{C}$ selama tiga menit; dan $4^{\circ} \mathrm{C}$ (tak hingga). Pengecekan hasil amplifikasi PCR dilakukan dengan elektroforesis menggunakan gel agarose $1 \%$.

Ekspresi gen $\mathrm{PhGH}$ secara fenotip dilakukan dengan mengukur bobot ikan lele berumur 5 bulan. Embrio ikan lele yang berasal dari telur yang dibuahi sperma yang dielektroforasi diinkubasi pada suhu $29^{\circ} \mathrm{C}$. Telur yang menetas dipelihara selama satu bulan dalam akuarium berukuran $60 \mathrm{~cm} \times 40$ $\mathrm{cm} \times 40 \mathrm{~cm}$ dengan kepadatan 20 ekor/L. Yuwana ikan lele umur satu bulan dipindahkan ke kolam beton berukuran $25 \mathrm{~m}^{2}$ dengan kepadatan 50 ekor $/ \mathrm{m}^{2}$ dan dipelihara selama lima bulan. Selama pemeliharaan ikan diberi pakan secara ad libitum dan pada wadah pemeliharaan diberi aerasi. Pengukuran bobot yuwana umur lima bulan dilakukan pada 90 individu dari perlakuan $100 \mu \mathrm{g} / \mathrm{mL}$ dan kontrol. Selanjutnya dibuat grafik distribusi bobot ikan lele dari masing-masing perlakuan.

\section{HASIL DAN BAHASAN}

\section{Keberhasilan Insersi Gen PhGH}

Pada saat sel sperma atau sel telur dielektroforasi, aplikasi kejutan listrik pada suspensi sel menginduksi polarisasi komponen membran sel dan mengembangkan potensi tegangan di seluruh membran. Pada saat perbedaan potensial antara bagian dalam dan luar membran sel melewati titik kritis, komponen membran direorganisasi ke dalam pori dalam area terlokalisasi, dan kemudian sel menjadi permeabel terhadap masuknya makromolekul (Knight, 1981; Knight \& Scrutton, 1986). Pada penelitian ini, keberadaan gen $\mathrm{PhGH}$ pada yuwana ikan lele terdeteksi pada ukuran 392 bp (Gambar 1). Keberadaan gen $\mathrm{PhGH}$ dideteksi pada populasi ikan lele hasil introduksi gen $\mathrm{PhGH}$ pada konsentrasi $50 \mu \mathrm{g} / \mathrm{mL}$ maupun $100 \mu \mathrm{g} / \mathrm{mL}$.

Keberhasilan insersi gen $\mathrm{PhGH}$ meningkat seiring dengan meningkatnya konsentrasi DNA plasmid (Tabel 1). Transfer gen $\mathrm{PhGH}$ menggunakan metode elektroforasi pada sperma dengan konsentrasi $100 \mu \mathrm{g} / \mathrm{mL}$ menunjukkan tingkat keberhasilan insersi gen terbaik dengan tingkat keberhasilan 56\%.

Efisiensi pengikatan DNA eksogen dengan menggunakan elektroforasi pada sperma ikan chinook salmon ditentukan oleh kekuatan
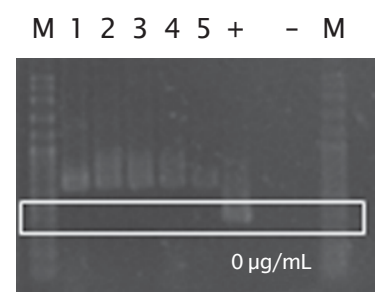

M $1223456678910+-M$

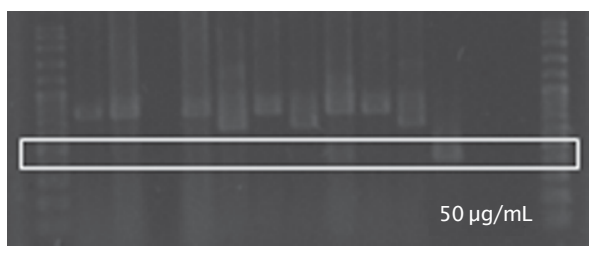

$\begin{array}{lllllllllll}M & 1 & 2 & 3 & 4 & 5 & 6 & 7 & 8 & 9 & 10+\end{array}$

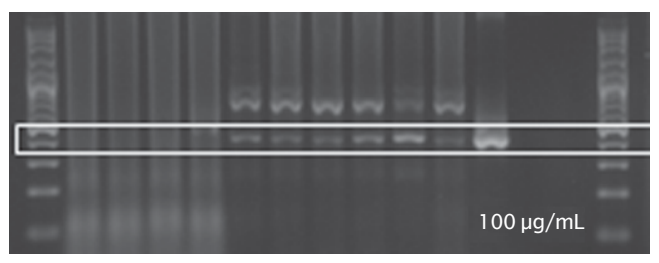

Gambar 1. Deteksi gen PhGh pada ikan lele pada konsentrasi DNA plasmid yang berbeda $(\mathrm{M}=$ marker DNA; $1-10=$ nomor individu; $(+)=$ kontrol positif (plasmid); $(-)=$ kontrol negatif (tanpa cetakan DNA); $\square$ (kotak putih) = fragmen gen $P h G H)$

Figure 1. Detection of PhGH gene in African catfish at different concentration of DNA plasmid ( $M=$ DNA marker; $1-10=$ individual number; $(+)=$ positive control (plasmid); $(-)=$ negative control (without DNA template); $\square($ white box $)=$ PhGH gene fragment)

medan listrik, jumlah kejutan listrik, dan konsentrasi DNA (Symonds et al., 1994). Hal yang sama juga telah dilaporkan oleh Walker et al. (1995) bahwa konsentrasi DNA dalam larutan mempengaruhi efisiensi keberhasilan transfer gen. Konsentrasi DNA yang tinggi meningkatkan efisiensi pengikatan DNA oleh sperma, dan meningkatkan efisiensi transfer pada telur. Pada penelitian ini, peningkatan konsentrasi DNA plasmid dari $50 \mu \mathrm{g} / \mathrm{mL}$ menjadi $100 \mu \mathrm{g} / \mathrm{mL}$ mampu meningkatkan keberhasilan insersi gen $\mathrm{PhGH}$ pada ikan lele dari 
Tabel 1. Keberhasilan insersi gen PhGH pada ikan lele

Table 1. The success of PhGH gene insertion in African catfish

\begin{tabular}{cccc}
\hline $\begin{array}{c}\text { Konsentrasi } \\
\text { DNA plasmid } \\
\text { Plasmid DNA } \\
\begin{array}{c}\text { concentration } \\
(\mu \mathrm{g} / \mathrm{mL})\end{array}\end{array}$ & $\begin{array}{c}\text { Jumlah individu } \\
\text { yang diperiksa } \\
\text { Number of sample } \\
\text { analyzed }\end{array}$ & $\begin{array}{c}\text { Jumlah individu } \\
\text { positif transgenik } \\
\text { Number of fish } \\
\text { positively transgenic }\end{array}$ & $\begin{array}{c}\text { Persentase individu } \\
\text { transgenik } \\
\text { Percentage of } \\
\text { transgenic fish }\end{array}$ \\
\hline 0 & 5 & 0 & 0 \\
50 & 30 & 1 & 3.3 \\
100 & 100 & 56 & 56 \\
\hline
\end{tabular}

3,3\% menjadi 56\%. Penelitian yang dilakukan oleh Dewi (2010) pada ikan patin siam menunjukkan adanya peningkatan insersi gen PhGH eksogen dari $28,57 \%$ menjadi $85,71 \%$ pada saat konsentrasi DNA plasmid ditingkatkan dari $10 \mu \mathrm{g} / \mathrm{mL}$ menjadi $90 \mu \mathrm{g} / \mathrm{mL}$.

Pada penelitian ini, transfer gen $\mathrm{pCCBA}$ PhGH dilakukan dengan menggunakan metode elektroforasi pada sperma yang berperan sebagai perantara. Menurut Spadafora (1998), pada proses transfer gen dengan perantara sperma, DNA eksogen terinternalisasi ke dalam nukleus sperma dan selanjutnya terintegrasi ke dalam genom sperma. Gen asing yang terintegrasi akan stabil di sel resipien, sementara dalam bentuk ekstrakromosomal akan terdegradasi oleh endogenous nuclease. Menurut Palmiter \& Brinster (1986), setelah DNA eksogen mengalami proses degradasi, seringkali DNA eksogen ditemukan dalam kondisi terintegrasi pada kromosom DNA inang. Mekanisme integrasi diduga melibatkan proses penggabungan dan rekombinasi bergantung pada pemotongan kromosom yang bersifat acak.

Interaksi antara DNA eksogen dan sel sperma bukan merupakan peristiwa yang acak, tetapi merupakan proses yang teratur yang diperantarai oleh faktor-faktor spesifik. Kemampuan spermatozoa dari hampir semua spesies untuk mengikat DNA asing telah terdokumentasi dengan baik. Individu yang ditransformasi secara genetik dari berbagai spesies telah diperoleh dengan menggunakan sel sperma sebagai vektor dari DNA asing. Hasil-hasil observasi ini menunjukkan bahwa SMGT (sperm mediated gene transfer) jika dikembangkan lebih jauh, dapat diaplikasikan dengan baik untuk tujuan bioteknologi dan dapat digunakan sebagai alat untuk trans- formasi transgenik pada hewan-hewan yang sulit dimikroinjeksi (Spadafora, 1998).

\section{Ekspresi Genotip dan Fenotip Gen PhGH Ikan Lele}

Analisis ekspresi gen $P h G H$ eksogen pada ikan lele dilakukan pada individu yang positif membawa gen $\mathrm{PhGH}$ eksogen pada sirip ekornya. Dari dua belas ekor ikan yang diamati, semuanya menunjukkan bahwa gen $\mathrm{PhGH}$ terekspresi pada ikan lele (Gambar 2). Hal ini menunjukkan bahwa promoter $\beta$-aktin ikan mas mampu mengendalikan ekspresi gen PhGH pada ikan lele dan telah terjadi overekspresi gen $P h G H$ pada sirip ikan lele. Gen $\mathrm{PhCH}$ yang ditransfer selain mampu terinsersi di dalam tubuh ikan lele juga terekspresi dengan baik, hal ini membuka peluang ditemukannya ikan lele transgenik founder. Menurut Sarmasik (2003), jika konstruksi transgen membawa promoter fungsional, sejumlah individu transgenik dapat diharapkan untuk mengekspresikan aktivitas transgen.

Perbedaan ekspresi fenotip berdasarkan karakter bobot antara ikan lele hasil introduksi gen $\mathrm{PhGH}$ dan kontrol dilakukan pada saat ikan lele berumur 5 bulan. Bobot ikan lele pada populasi hasil introduksi gen $\mathrm{PhGH}$ lebih bervariasi dibandingkan dengan populasi kontrol (Gambar 3). Berdasarkan distribusi bobot, pada populasi hasil introduksi gen $\mathrm{PhGH}$ terdapat dua ekor ikan lele yang bobotnya hampir dua kali lipat dibandingkan bobot rataan populasi kontrol (Gambar 3).

Menurut Inoue et al. (1990), level ekspresi transgen bervariasi di antara individu transgenik. Hal ini dikarenakan antara lain karena bervariasinya jumlah transgen yang terintegrasi dan situs integrasi pada individu 


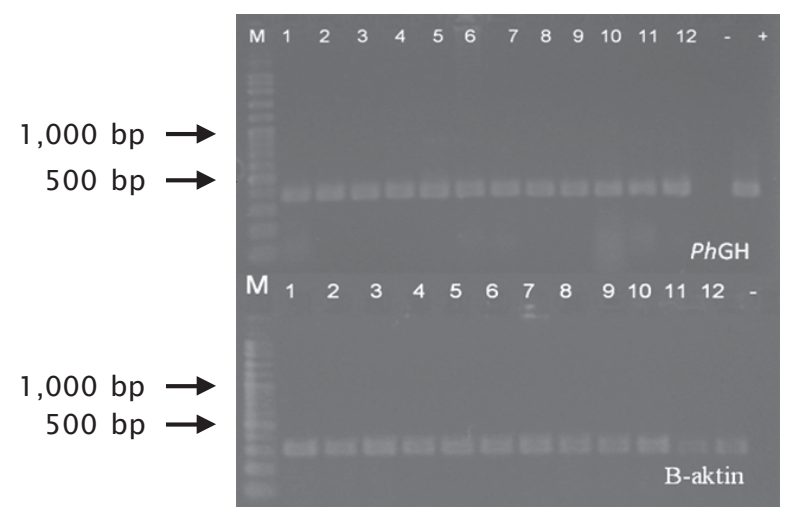

Gambar 2. Ekspresi mRNA PhGH pada sirip individu ikan lele transgenik (A) dan mRNA $\beta$-aktin ikan lele $(B)$ sebagai kontrol internal $(M=$ marker DNA; $1-12=$ nomor individu transgenik; $(+)=$ kontrol positif (plasmid); $(-)=$ kontrol negatif (tanpa cetakan DNA); 500 bp dan $1.000 \mathrm{bp}=$ ukuran marker)

Figure 2. Expression of PhGH mRNA on African catfish transgenic (A) and $\beta$-actin MRNA $(B)$ as internal control $(M=D N A$ marker; $1-12=$ transgenic individual number; $(+)=$ positive control (plasmid); $(-)=$ negative control (without DNA template); $500 \mathrm{bp}$ and 1,000 bp = size marker)

yang berbeda. Individu ikan lele yang diintroduksi gen PhGH memiliki bobot badan yang bervariasi. Beberapa individu berukuran lebih besar, sebagian lainnya tidak berbeda dan sebagian kecil lainnya lebih kecil dibandingkan yang non-transgenik. Hasil penelitian ini sama dengan penelitian Zhu et al. (1985) yang melakukan penelitian pada ikan mas yang ditranfer gen MThGH. Berdasarkan penelitian ini, beberapa individu transgenik menunjukkan peningkatan laju pertumbuhan yang signifikan, beberapa individu berukuran lebih kecil dibandingkan kontrol dan bahkan beberapa individu menunjukkan morfologi yang abnormal. Hal ini dapat terjadi terkait dengan lokasi integrasi yang mempengaruhi ekspresi dan berfungsinya transgen. Tiga kategori ekspresi berdasarkan lokasi integrasi yaitu: functional integration, silent integration, dan toxic integration $\mathrm{Wu}$ et al., 2003).

Respons fenotip dari ekspesi transgen bervariasi di antara individu. Pada populasi ikan lele yang diintroduksi gen $\mathrm{PhGH}$, terdapat dua individu yang memiliki pertumbuhan tercepat yaitu hampir dua kali lipat dibandingkan rataan bobot non-transgenik. Pada ikan loach transgenic founder, di mana gen (opAFPscGHc) ditransfer dengan menggunakan metode elektroforasi pada sperma, pertumbuhan meningkat sampai dua kali lipat dibandingkan kontrol (Tsai, 2000). Adapun pada ikan ayu (Plecoglossus altivelis), elektroforasi konstruksi gen caBA-rtGHc dengan perantara sperma, mampu meningkatkan bobot ikan ayu transgenik founder sampai dua kali lipat dibandingkan non-transgenik (Cheng et al., 2002). Transfer konstruksi gen caBA-rtGHc dengan perantara sperma pada ikan silver sea bream (Rhabdosargus sarba), menunjukkan bahwa beberapa individu transgenik menunjukkan pertumbuhan dua kali lipat lebih tinggi dibandingkan non-transgenik (Lu et al., 2002). Transfer konstruksi gen AFP-csGHc pada ikan salmon Atlantik, mampu meningkatkan pertumbuhan 2-6 kali dibandingkan kontrol (Du et al., 1992).

\section{KESIMPULAN}

Transfer gen PhGH menggunakan metode elektroforasi melalui perantaraan sperma ikan lele menunjukkan bahwa gen PhGH telah berhasil terinsersi dan terekspresi pada ikan lele. Konsentrasi DNA plasmid terbaik untuk menghasilkan individu yang positif membawa gen $P h G H$ adalah pada konsentrasi $100 \mu \mathrm{g} /$ $\mathrm{mL}$. Pada populasi ikan lele yang ditransfer gen $\mathrm{PhGH}$ ditemukan dua individu yang memiliki bobot hampir dua kali lipat dibandingkan populasi kontrol. Dengan demikian generasi F-0 ikan lele cepat tumbuh telah berhasil diproduksi. 

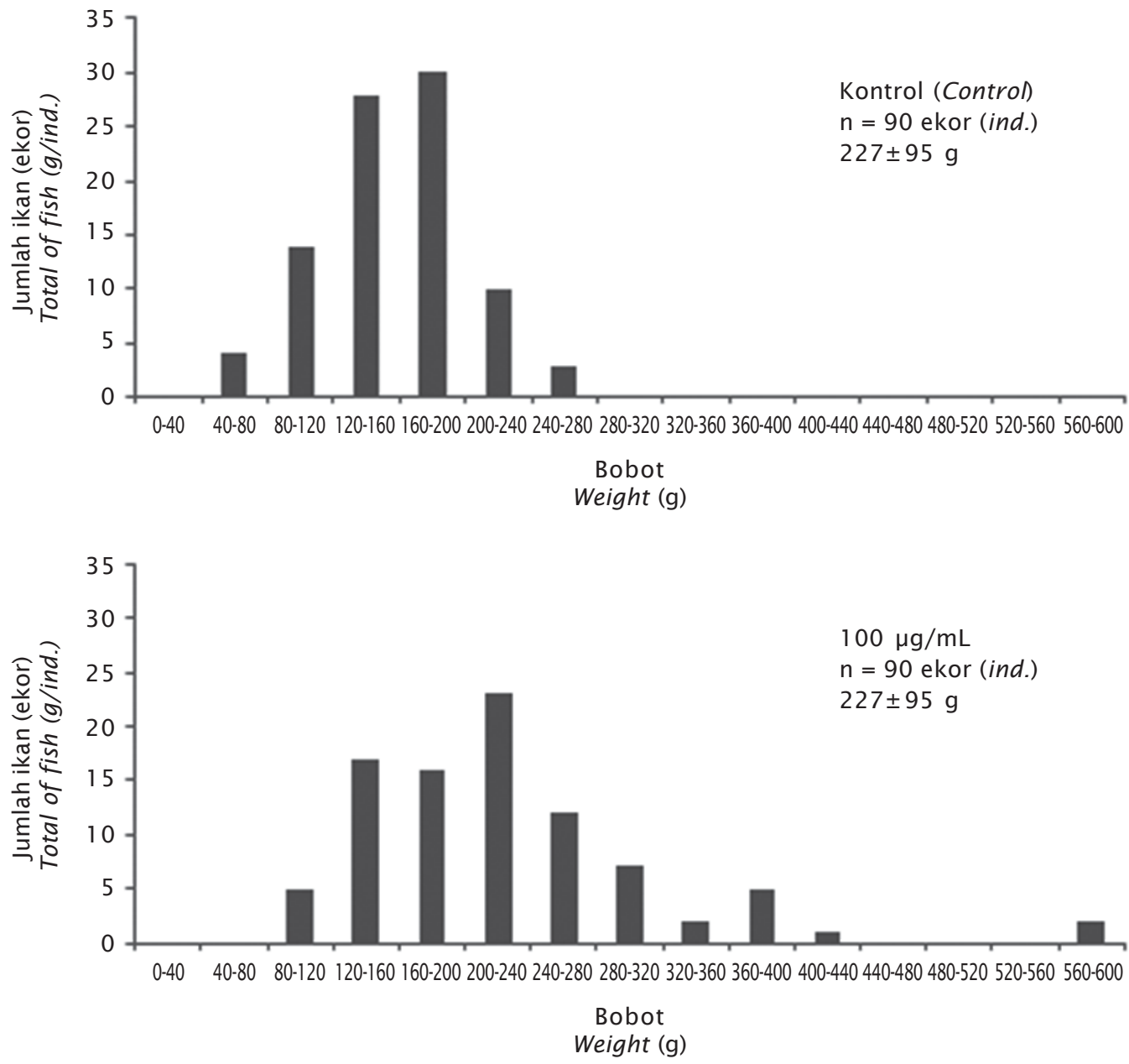

Gambar 3. Distribusi bobot ikan lele pada populasi kontrol dan populasi hasil introduksi gen PhGH pada umur 5 bulan

Figure 3. Weight distribution of African catfish in the control population and the introduction of PhGH genes population at the age of 5 months

\section{DAFTAR ACUAN}

Beardmore, J.A. \& Porter, J.S. 2003. Genetically modified organisms and aquaculture. FAO Fisheries Circular. No. 989. Rome, 35 pp.

Cheng, C.A., Lu, K.L., Lau, E.L., Yang, T.Y., Lee, C.Y., Wu, J.L., \& Chang, C.Y. 2002. Growth promotion in ayu (Plecoglossus altivelis) by gene transfer of the rainbow trout growth hormone gene. Zool. Stud., 41 (3): 303-310.

Devlin, R.H., Yesaki, T.Y., Biagy, C.A., Donaldson, E.M., Swanson, P., \& Chan, W.K. 1994. Extraordinary salmon growth. Nature, 371 : 209-210.
Devlin, R.H., Yesaki, T.Y., Donaldson, E.M., \& Hew, C.L. 1995. Transmission and phenotypic effects of an antifreeze/GH gene construct in coho salmon (Oncorhynchus kisutch). Aquaculture, 137: 161-169.

Dewi, R.R.S.P.S. 2010 . Studi over-ekspresi gen penyandi hormon pertumbuhan melalui elektroforesis sperma untuk membuat ikan patin siam transgenik cepat tumbuh. Disertasi. $75 \mathrm{hlm}$.

Du, S.J., Gong, Z., Fletcher, G.L., Shears, M.A., King, M.J., Idler, D.R., \& Hew, C.L. 1992. Growth enhancement in transgenic Atlantic salmon by the use of an "all fish" chi- 
meric growth hormone gene construct. Biol. Tech., 10: 176-180.

Gusrina, Alimuddin, Sumantadinata, K., \& Widyastuti, U. 2009. Transfer gen penyandi hormon pertumbuhan ikan nila (tiGH) pada ikan lele (Clarias sp.) dengan metode mikroinjeksi. J. Ris. Akuakultur, 4(3): 333340.

Hinits, Y. \& Moav, B. 1999. Growth performance studies in transgenic Cyprinus carpio. Aquaculture, 173: 285-296.

Inoue, K., Yamashita, S., Hata, J., Kabeno, S., Asada, S., Nagahisa, E., \& Fujita, T. 1990. Electroporation as a new technique for producing transgenic fish. Cell. Differ. Dev., 29: 123-128.

Knight, D.E. 1981. Rending cells permeable to exposure to electric fields. Tech. Cell. Physiol., 113: 1-10.

Knight, D.E. \& Scrutton, M.C. 1986. Gaining access to the cytosol: the technique and some application of electropermeabilization. Biochem. J., 234: 497-506.

Kobayashi, S., Alimuddin, Morita, T., Miwa, M., Lu, J., Endo, M., Takeuchi, T., \& Yoshizaki, G. 2007. Transgenic Nile tilapia (Oreochromis niloticus) over expressing growth hormone show reduced ammonia excretion. Aquaculture, 270: 427-435.

Lu, J.K., Fu, B.H., Wu, J.L., \& Chen, T.T. 2002. Production of transgenic silver sea bream (Sparus sarba) by different gene transfer methods. Mar. Biotechnol., 4: 328-337.

Nam, Y.K., Noh, J.K., Cho, Y.S., Cho, H.J., Cho, K.N., Kim, G., \& Kim, D.S. 2001. Dramatically accelerated growth and extraordinary gigantism of transgenic mud loach Misgurnus mizolepis. Trans. Res., 10: 353-362.

Palmiter, R.D. \& Brinster, R.L. 1986. Germ-line transformation of mice. Ann. Rev. Genet., 20: 465-499.
Powers, D.A., Hereford, L., Cole, T., Chen, T.T., Lin, C.M., Knight, K., Creech, K., \& Dunham, R. 1992. Electroporation method for transferring genes into the gametes of zebrafish (Brachydanio rerio), channel catfish (Ictalurus punctatus), and common carp (Cyprinus carpio). Mol. Mar. Biol. Biotechnol., 1: 301-308.

Sarmasik, A. 2003. Application of gene transfer technology for genetic improvement of fish. Tech. J. Zool., 27: 1-6.

Spadafora, C. 1998. Sperm cells and foreign DNA: a controversial relation. Bioessays, 20: 955-964.

Symonds, J.E., Walker, S.P., \& Sin, F.Y.T. 1994. Development of mass gene transfer method in Chinook salmon: optimization of gene transfer by electroporated sperm. Mol. Mar. Biotechnol., 3: 104-111.

Tsai, H.J., Tseng, F.S., \& Liao, I.C. 1995. Electroporation of sperm to introduce foreign DNA into the genome of loach (Misgurnus anguilicaudatus). Can. J. Fish. Aquat. Sci., 52: 776-787.

Tsai, H.J. 2000. Electroporated sperm mediation of a gene transfer system for finfish and shellfish. Mol. Repro. Dev., 56: 281-284.

Tsong, T.Y. 1983. Voltage modulation of membrane permeability and energy utilization in cells. Biosci. Rep., 3: 487-505.

Walker, S.T., Symonds, J.E., Sin, I.L., \& Sin, F.Y.T. 1995. Gene transfer by electroporated Chinook salmon sperm. J. Mar. Biotech., 3: 232-234.

Wu, G., Sun, Y., \& Zhu, Z. 2003. Growth hormone gene transfer in common carp. Aquat. Living Resour., 16: 416-420.

Zhu, Z., Li, G., He, L., \& Chen, S. 1985. Novel gene transfer into the fertilized eggs of goldfish (Carassius auratus L. 1758). J. Appl. Ichthyol., 1: 31-34. 